\title{
Polymorphisms of the DAX1 and EGR4 Genes are Not Common Causes of Abnormal Spermatogenesis
}

\author{
Lihua Liu, Benjamin R. Emery and Douglas T. Carrell ${ }^{*}$
}

Andrology and IVF Laboratories, Department of Surgery, University of Utah School of Medicine, Salt Lake City, UT, USA

\begin{abstract}
The study of gene mutations causing sequence variation in spermatogenesis-related genes has revealed a highly stable spermatogenic code with little variability and even fewer disease-causing mutations. The current study supports the same trend, indicating that EGR4 and DAX1, two spermatogenesis-related genes, have a high genetic fidelity and do not contain polymorphic sites that would lead to a disease state. This was determined from a population of 192 men, 96 control samples from men with known paternity, acquired from the Utah Genetic Reference Project (UGRP), and 96 infertile men. The diagnosis of the infertile men was stratified amongst three diagnostic groups, non-obstructive azoospermic, severe oligozoospermic, and men with abnormal protamine expression.
\end{abstract}

Keywords: Spermatogenesis, gene sequence, male infertility.

\section{INTRODUCTION}

Of the $15 \%$ of couples who experience infertility, approximately half involve some degree of male factor infertility [1], and more than half of male infertility has uncertain causes [2]. Genetic factors may account for a substantial proportion of male infertility causes [3]. Animal gene targeting studies have provided a long list of candidate genes related to male infertility [4-8], but only a limited number of studies have evaluated the role of these genes in human infertility.

Spermatogenesis is the biological process of gradual transformation of germ cells into spermatozoa. This process involves various activities: cellular proliferation by repeated mitotic divisions, reductive division by meiosis to produce haploid spermatids, and finally, spermiogenesis, the process by which spermatids are differentiated into spermatozoa. Any factors that affect spermatogenesis can cause male infertility. Approximately two thousand genes have been identified as important participants in spermatogenesis $[9,10]$.

The Egr family of zinc-ginger transcription factors (Egr1, Egr2, Egr3, and Egr4) is thought to regulate critical genetic programs involved in cellular growth and differentiation [11]. All the members of the Egr family include a DNAbinding domain comprised of 3 zinc-fingers motifs, which recognize the Egr response element of the target genes to regulate their expression [12]. Gene targeting experiments in mice showed that the Egr4 null female is fertile, but the male is infertile without other obvious abnormalities. The germ cell maturation in male mice is nearly completely blocked at the early-mid pachytene stage, leading to oligozoospermia characterized by the production of a comparatively small

*Address correspondence to this author at the Andrology and IVF Laboratories, Department of Surgery, University of Utah School of Medicine, $675 \mathrm{~S}$. Arapeen Dr., Suite \#205, Salt Lake City, UT 84108, USA;

E-mail: Douglas.carrell@hsc.utah.edu number of spermatozoa with abnormal morphology. Interestingly, Egr4 also seems to be expressed first at the early-mid pachytene stage of spermatocyte maturation [11].

Dax1, also known as NR0B1 (nuclear receptor subfamily 0 , group $\mathrm{B}$, member 1 ), encodes a protein that plays an important role in the normal development of the adrenal glands, the pituitary gland, and the hypothalamus. Mutations of this gene in human can result in X-linked adrenal hypoplasia congenital (AHC) and hypogonadotropic hypogonadism [1318]. The mouse model with partially deleted Dax 1 gene showed that the germinal epithelial integrity had been damaged, but the spermatogenesis did not completely stop until after 14 weeks. The serum LH and FSH of those male mice are indistinguishable from those of wild-type mice, which means the hypogonadism is more likely the result of the primary testicular failure [19]. The Sertoli cell-specific expression of a Dax 1 transgene can partially reverse the effect of primary testicular failure seen in dax1-deficient mice. Fertility was restored in these mice, but the testicular morphology was only partially improved [20]. The abnormal differentiation and proliferation of Leydig cells and Sertoli cells in Dax 1 deficient male mice cause obstruction of the rete testis and infertility [21].

Our laboratory has recently undertaken a program of medical resequencing of male infertility candidate genes in men with otherwise unexplained azoospermia or severe oligozoospermia and identified novel polymorphisms associated with male infertility [22]. The purpose of this study was to evaluate polymorphisms of two candidate genes, EGR 4 and DAX1, in three classes of male infertility patients and in fertile controls.

\section{MATERIALS AND METHODS}

\section{Study Population}

Institutional Review Board (IRB) approval was obtained for all aspects of this study. A total 96 infertile patients, 30 
azoospermic, 34 oligospermic $\left(<5 \times 10^{6}\right.$ sperm $\left./ \mathrm{mL}\right)$ and 32 abnormal protamine profile patients, were included in this study. The cut-off values for abnormal protamine 1 to protamine $2(\mathrm{P} 1 / \mathrm{P} 2)$ ratio was determined in a previous study in our lab as less than 0.8 or greater than 1.2 [23]. Exclusion criteria included karyotype abnormalities, Y chromosome microdeletions, and CFTR mutations. DNA from 96 men with known paternity were obtained from the Utah Genetic Reference Project (UGRP) and included as fertile controls. Semen quality from these control subjects is unknown, and likely variable.

\section{Egr4 and Dax1 Gene Screening}

Venous blood was obtained using standard phlebotomy techniques and the genomic DNA extracted with the Puregene DNA extraction kit (Minneapolis, MN). Primer sets were designed and optimized to amplify Egr4 gene (Gene ID: 1961) (Table 1) and Daxl gene (Gene ID: 190) (Table 2). The Egr4 gene sequencing included the $400 \mathrm{bp}$ intron, but the Dax 1 gene sequencing mainly focused on exons. Primary PCR products were cleaned using ExoSap-it (USB, Cleveland, Ohio), and sequenced in the forward and reverse directions. Samples were sequenced using ABI 3730XL sequencer (Applied Biosystems, Inc., Foster City, CA). Sequence traces were assembled and analyzed for significant changes using Phred/Phrap and Consed software (www.phrap.org).

\section{Statistical Analysis}

The comparison of the frequency of SNPs between control and patient groups was analyzed by using Yates Chi Square analysis.

\section{RESULTS}

The gene sequencing started with 96 control and 96 infertile patients: 32 abnormal P1/P2 ratio patients and 64 azoospermic or oliogozoospermic patients. The results reported here are based on the number clean sequences obtained after optimization and data analysis using Pred/Phrap, Consed.

Analysis of the Egr4 gene region revealed a total of 8 single nucleotide polymorphisms (SNPs) in this study (Table 3). Five of them were within the 5'UTR or 3'UTR regulatory regions, 1 within the single gene intron and 2 within the gene coding region. The 2 SNPs within the coding region do not alter the amino acid sequence. Two of the SNPs, which have been reported in National Center for Biotechnology Information (NCBI) database (rs7558708, rs2229294), were identified in both control and the patient population. Although the frequency of the SNP rs7558708 (0.367) and the SNP rs2229294 (0.333) in abnormal P1/ P2 ratio group were higher than those $(0.185$ and 0.200$)$ in the control group, there are no statistical differences, $\mathrm{P}>0.05$. The frequencies of rs7558708 and rs2229294 in azoospermic / oligozoospermic patient group were similar to those in the control group. The other 6 SNPs were not reported in the database, but the frequencies were low $(0.012 \sim 0.032)$. None of the SNPs identified in this study causes an amino acid sequences alteration.

There were only 2 SNPs in the Dax 1 gene identified (Table 4). Both of them have been reported in NCBI database (rs6150 and rs2269345) and were synonymous SNPs. There were no statistical differences between control samples and patient samples by using Yeats $\mathrm{x}^{2}$ analysis, $\mathrm{P}>0.05$.

\section{DISCUSSION}

Gene knock-out studies in mice have shown that Egr4deficiency causes infertility associated with incomplete spermatogenetic arrest and oligozoospermia. Targeting of Dax 1 caused progressive degeneration of the testicular germinal epithelium and resulted in male sterility. In this study, we have sequenced the Egr4 and Dax1 genes in ninety-six infertile patients with either oligozoospermia, or azoospermia (64 men), and men with abnormal protamine expression (32 men). While novel SNPs were identified, the frequencies were low and did not result in amino acid changes in the proteins. There were no statistical differences of the frequencies of all the SNPs between control group and the two different infertile patient groups.

Since gene expression may be modulated during, transcription, translation, or post-translation modification, the lack of sequence variability does not necessarily rule out the possibility of abnormal protein expression. DNA sequence alterations in gene regulatory regions of DAX1 and Egr4 were not fully evaluated and cannot be ruled out as a possible cause of gene expression abnormalities [24-27].

These data suggest that it is unlikely that genetic sequence aberrations in the exon region of these two genes are

Table 1. Primers for Egr4 Gene PCR Amplification

\begin{tabular}{|c|c|c|c|c|}
\hline Exon $1-2$ & GAGCTTTCCTTTTCGGGAGT & GCCTGGTAGTCTCCCTGTGA & $62^{\circ} \mathrm{C}$ & 1477 \\
\hline Exon 2 & AGAGTTGTGTGCGGAGCTTT & AGCCCTTAGGTGAGCTGTGA & $62^{\circ} \mathrm{C}$ & 1058 \\
\hline
\end{tabular}

Table 2. Primers for Dax1 Gene PCR Amplification

\begin{tabular}{|c|c|c|c|}
\hline Exon & Forward (5'-3') & Reverse (5'-3') & Annealing Temperature \\
\hline \hline Exon 1 & ACGCTGCTGTTCTTCCATTT & AACAACTCCCCTCCTCTTGG & $62^{\circ} \mathrm{C}$ \\
\hline Exon 2 & TCTTGGACACGTTGCTTCTG & GCAGGTTCCATGAAATTGCT & 1620 \\
\hline
\end{tabular}


Table 3. SNP in Patients, Control, and in Database (Egr4)

\begin{tabular}{|c|c|c|c|c|c|c|}
\hline \multicolumn{3}{|c|}{ EGR4 } & \multicolumn{4}{|c|}{ Allelic Frequency } \\
\hline $\begin{array}{l}\text { Nucleotide } \\
\text { Location }\end{array}$ & $\begin{array}{c}\text { Amino } \\
\text { Acid }\end{array}$ & $\begin{array}{l}\text { dbSNP } \\
\text { ID }\end{array}$ & $\begin{array}{l}\text { Controls } \\
\text { (UGRP) }\end{array}$ & $\begin{array}{c}\text { Azoo/oligozoospermic } \\
\text { Patients }\end{array}$ & $\begin{array}{c}\text { Abnormal P1/P2 } \\
\text { Ratio Patients }\end{array}$ & $\underset{\text { Report }}{\text { Hap-Map }}$ \\
\hline $\mathrm{CCCA}[\mathrm{G} / \mathrm{A}] \mathrm{AGGT}$ & 5'UTR & Novel & 0.000 & - & $0.032(1 / 31)$ & - \\
\hline GGAG[G/A]GCGA & 5'UTR & Novel & 0.000 & - & $0.032(1 / 30)$ & - \\
\hline $\mathrm{CGCC}[\mathrm{G} / \mathrm{C}] \mathrm{CGGC}$ & 5"UTR & Novel & $0.026(2 / 78)$ & 0.000 & - & - \\
\hline $\mathrm{CACC}[\mathrm{C} / \mathrm{T}] \mathrm{GCAC}$ & P95L & rs35980039 & 0.000 & 0.000 & - & 0.025 \\
\hline AGCC $[\mathrm{C} / \mathrm{G}] \mathrm{GGCC}$ & P184P & Novel & 0.000 & $0.016(1 / 63)$ & - & - \\
\hline $\mathrm{ACCA}[\mathrm{A} / \mathrm{C}] \mathrm{GGAG}$ & Intronic & Novel & $0.012(1 / 81)$ & 0.000 & - & - \\
\hline TGGC[C/G]TGGG & Q353H & rs13394919 & 0.000 & 0.000 & - & - \\
\hline GACG[A/C]AAGG & $\mathrm{R} 358 \mathrm{R}$ & rs533641 & 0.000 & 0.000 & - & - \\
\hline CGGA[A/G]CGCG & R393R & rs7558708 & $0.185(15 / 81)$ & $0.161(9 / 56)$ & $0.367(11 / 30)$ & 0.306 \\
\hline AGCC[C/T]TTTG & P437P & rs35362064 & 0.000 & 0.000 & - & 0.030 \\
\hline CTGG[A/G]AGCG & 3'UTR & rs 7584540 & 0.000 & 0.000 & - & - \\
\hline AGTT[C/T]CGGG & 3'UTR & rs2229294 & $0.200(5 / 25)$ & $0.200(12 / 60)$ & $0.333(10 / 30)$ & 0.154 \\
\hline $\mathrm{CGCG}[\mathrm{C} / \mathrm{A}] \mathrm{TCCG}$ & 3'UTR & Novel & 0.000 & - & $0.032(1 / 30)$ & - \\
\hline
\end{tabular}

For all comparisons of patients to controls, $\mathrm{P}>0.05$

Table 4. SNP in Patients, Control, and in Database (DAX1)

\begin{tabular}{|c|c|c|c|c|c|c|}
\hline \multicolumn{4}{|c|}{ NR0B1(DAX1) } & \multicolumn{3}{c|}{ Allelic Frequency } \\
\hline $\begin{array}{c}\text { Nucleotide } \\
\text { Location }\end{array}$ & $\begin{array}{c}\text { Amino } \\
\text { Acid }\end{array}$ & $\begin{array}{c}\text { dbSNP } \\
\text { ID }\end{array}$ & $\begin{array}{c}\text { Controls } \\
\text { (UGRP) }\end{array}$ & $\begin{array}{c}\text { Azoo/oligozoospermic } \\
\text { Men }\end{array}$ & $\begin{array}{c}\text { Abnormal } \\
\text { P1/P2 }\end{array}$ & $\begin{array}{c}\text { Hap-Map } \\
\text { Report }\end{array}$ \\
\hline \hline AGTG[C/T]TGGG & C38C & rs6150 & $0.210(17 / 81)$ & $0.145(9 / 62)$ & $0.125(4 / 32)$ & 0.280 \\
\hline CACG[A/G]CCAG & R166R & rs2269345 & $0.220(15 / 68)$ & $0.349(22 / 63)$ & $0.188(6 / 32)$ & - \\
\hline GCTG[C/G]GCGT & W291C & rs28935482 & 0.000 & 0.000 & - \\
\hline TCAA[G/T]GGGA & K382K & rs28935180 & 0.000 & 0.000 & - \\
\hline ATTC[A/T]GGGA & L410Q & rs11550590 & 0.000 & 0.000 & & \\
\hline ATCA[A/T]TGCC & N440I & rs28935481 & 0.000 & 0.000 & - \\
\hline
\end{tabular}

common causes of protamine deficiency, azoospermia, or oligozoospermia in men. Although, normal gene sequence of Egr4 and Dax1 in infertile patients does not necessarily rule out the possibility that these gene products are involved in male infertility. Direct protein level comparison between infertile and fertile men should be done in order to identify the relationship between these two genes and male fertility status.

\section{REFERENCE}

[1] Carrell DT, De Jonge C, Lamb DJ. The genetics of male infertility: a field of study whose time is now. Arch Androl 2006; 52: 269-74.

[2] Nishimune $\mathrm{Y}$, Tanaka $\mathrm{H}$. Infertility caused by polymorphisms or mutations in spermatogenesis-specific genes. J Androl 2006; 27: 326-34.

[3] Lilford R, Jones AM, Bishop DT, Thornton J, Mueller R. Casecontrol study of whether subfertility in men is familial. BMJ 1994; 309: 570-3.

[4] Yang J, Morales CR, Medvedev S, Schultz RM, Hecht NB. In the absence of the mouse DNA/RNA-binding protein MSY2, messen- ger RNA instability leads to spermatogenic arrest. Biol Reprod 2007; 76: 48-54.

[5] Kuznetsov S, Pellegrini M, Shuda K, et al. RAD51C deficiency in mice results in early prophase I arrest in males and sister chromatid separation at metaphase II in females. J Cell Biol 2007; 176: 58192.

[6] Hrabchak C, Henderson H, Varmuza S. A testis specific isoform of endophilin B1, endophilin B1t, interacts specifically with protein phosphatase-1c gamma2 in mouse testis and is abnormally expressed in PP1c gamma null mice. Biochemistry 2007; 46: 463544.

[7] Christensen GL, Carrell DT. Animal models of genetic causes of male infertility. Asian J Androl 2002; 4: 213-9.

[8] Yang J, Medvedev S, Yu J, Schultz RM, Hecht NB. Deletion of the DNA/RNA-binding protein MSY2 leads to post-meiotic arrest. Mol Cell Endocrinol 2006; 250: 20-4.

[9] Cooke HJ, Hargreave T, Elliott DJ. Understanding the genes involved in spermatogenesis: a progress report. Fertil Steril 1998; 69: 989-95.

[10] Sassone-Corsi P. Transcriptional checkpoints determining the fate of male germ cells. Cell 1997; 88: 163-6.

[11] Tourtellotte WG, Nagarajan R, Auyeung A, Mueller C, Milbrandt J. Infertility associated with incomplete spermatogenic arrest and 
oligozoospermia in Egr4-deficient mice. Development 1999; 126: 5061-71.

[12] O'Donovan KJ, Tourtellotte WG, Millbrandt J, Baraban JM. The EGR family of transcription-regulatory factors: progress at the interface of molecular and systems neuroscience. Trends Neurosci 1999; 22: 167-73.

[13] Mericq V, Ciaccio M, Marino R, et al. A new DAX-1 mutation in a family with a case of neonatal adrenal insufficiency and a sibling with adrenal hypoplasia and sudden death at 3 years of age. J Pediatr Endocrinol Metab 2007; 20: 1039-43.

[14] Calliari LE, Longui CA, et al. A novel mutation in DAX1 gene causing different phenotypes in three siblings with adrenal hypoplasia congenita. Genet Mol Res 2007; 6: 177-83.

[15] Mantovani G, De Menis E, Borretta G, et al. DAX1 and X-linked adrenal hypoplasia congenita: clinical and molecular analysis in five patients. Eur J Endocrinol 2006; 154: 685-9.

[16] Bernard P, Ludbrook L, Queipo G, et al. A familial missense mutation in the hinge region of DAX1 associated with late-onset AHC in a prepubertal female. Mol Genet Metab 2006; 88: 272-9.

[17] Balsamo A, Antelli A, Baldazzi L, et al. A new DAX1 gene mutation associated with congenital adrenal hypoplasia and hypogonadotropic hypogonadism. Am J Med Genet A 2005; 135: 292-6.

[18] Krone N, Riepe FG, Dorr HG, et al. Thirteen novel mutations in the NR0B1 (DAX1) gene as cause of adrenal hypoplasia congenita. Hum Mutat 2005; 25: 502-3.

[19] Yu RN, Ito M, Saunders TL, Camper SA, Jameson JL. Role of Ahch in gonadal development and gametogenesis. Nat Genet 1998; 20: $353-7$
[20] Jeffs B, Ito M, Yu RN, et al. Sertoli cell-specific rescue of fertility, but not testicular pathology, in Dax1 (Ahch)-deficient male mice. Endocrinology 2001; 142: 2481-8.

[21] Jeffs B, Meeks JJ, Ito M, et al. Blockage of the rete testis and efferent ductules by ectopic Sertoli and Leydig cells causes infertility in Dax1-deficient male mice. Endocrinology 2001; 142: 4486-95.

[22] Hammoud S, Emery BR, Dunn D, Weiss RB, Carrell DT. Sequence alterations in the YBX2 gene are associated with male factor infertility. Fertil Steril 2008.

[23] Aoki VW, Liu L, Carrell DT. Identification and evaluation of a novel sperm protamine abnormality in a population of infertile males. Hum Reprod 2005; 20: 1298-306.

[24] Thomas KH, Meyn P, Suttorp N. Single nucleotide polymorphism in 5'-flanking region reduces transcription of surfactant protein B gene in H441 cells. Am J Physiol Lung Cell Mol Physiol 2006; 291: L386-90.

[25] Belbin O, Dunn JL, Ling Y, et al. Regulatory region single nucleotide polymorphisms of the apolipoprotein $\mathrm{E}$ gene and the rate of cognitive decline in Alzheimer's disease. Hum Mol Genet 2007; 16: 2199-208.

[26] Ladenvall P, Wall U, Jern S, Jern C. Identification of eight novel single-nucleotide polymorphisms at human tissue-type plasminogen activator (t-PA) locus: association with vascular t-PA release in vivo. Thromb Haemost 2000; 84: 150-5.

[27] Tong Z, Yang Z, Patel S, et al. Promoter polymorphism of the erythropoietin gene in severe diabetic eye and kidney complications. Proc Natl Acad Sci USA 2008; 105: 6998-7003. 